Jurnal Evaluasi dan Pembelajaran

Volume 3 Nomor 1, Tahun 2021

Available online at https://jepjurnal.stkipalitb.ac.id/index.php/hepi

\title{
PENINGKATAN AKTIVITAS BELAJAR KEBUGARAN JASMANI MELALUI METODE DEMONSTRASI PADA SISWA KELAS V SDN 4 SAWAH LAMA
}

\author{
Sajidin \\ SD Negeri 4 Sawah Lama
}

\begin{abstract}
Abstrak
Tujuan penelitian ini adalah untuk mengetahui apakah penggunaan metode demonstrasi dapat meningkatkan aktifitas belajar Kebugaran Jasmani Penjas Orkes pada siswa kelas V SD Negeri 4 Sawah Lama Tahun Pelajaran 2018/2019. Penelitian ini dilaksanakan di SD Negeri 4 Sawah Lama Kecamatan Tanjung Karang Timur Bandar Lampung Semester Genap Tahun Pelajaran 2018/2019. Subjek dalam penelitian ini adalah siswa kleas V SD Negeri 4 Sawah Lama Kecamatan Tanjung Karang Timur Bandar Lampung Semester Genap Tahun Pelajaran 2018/2019, berjumlah 27 orang yang terdiri dari 13 siswa laki-laki dan 14 siswa perempuan. Penelitian ini dapat dikategorikan berhasil jika: 75\% siswa aktif/sangat aktif mengikuti proses pembelajaran demonstrasi, dengan demikian siklus penelitian dihentikan. Hasil penelitian pada proses pembelajaran Kebugaran Jasmani Penjas Orkes dengan menggunakan metode demonstrasi pada siswa kelas V SD Negeri 4 Sawah Lama Tahun Pelajaran 2018/2019, yaitu pada siklus 1 kinerja guru mencapai 66,67\% dan aktivitas siswa mencapai $62,69 \%$. Pada siklis II kinerja guru mencapai 77,08\% dan aktivitas siswa mencapai 70,37\%. Pada siklus III kinerja guru mencapai $87,50 \%$ dan aktivitas siswa mencapai $77,78 \%$.
\end{abstract}

Kata Kunci: Aktivitas, Metode Demonstrasi, Siswa

\begin{abstract}
The purpose of this study was to determine whether the use of the demonstration method could improve physical fitness learning activities for the Physical Health Orchestra in grade V SD Negeri 4 Sawah Lama for the 2018/2019 academic year. This research was conducted at SD Negeri 4 Sawah Lama, Tanjung Karang Timur District, Bandar Lampung, even semester of the 2018/2019 academic year. The subjects in this study were students of class V SD Negeri 4 Sawah Lama, Tanjung Karang Timur District, Bandar Lampung, even semester of the 2018/2019 academic year, totaling 27 people consisting of 13 male students and 14 female students. This research can be categorized as successful if: $75 \%$ of students are active / very active in participating in the demonstration learning process, thus the research cycle is stopped. The results of the research on the physical fitness learning process of Physical Health Orchestra using the demonstration method in class V SD Negeri 4 Sawah Lama for the 2018/2019 academic year, namely in cycle 1 teacher performance reached $66.67 \%$ and student activity reached $62.69 \%$. In the second cycle, the teacher's performance reached $77.08 \%$ and student activity reached $70.37 \%$. In the third cycle the teacher's performance reached $87.50 \%$ and student activity reached $77.78 \%$.
\end{abstract}

Keywords: Activities, Demonstration Methods, Students 


\section{Pendahuluan}

Pendidikan adalah tentang bagaimana meningkatkan hasil belajar siswa. Hal ini akan terus berlanjut agar generasi penerus dapat tumbuh dan berdaya saing. Pendidikan merupakan salah satu hal penting dan berperan dalam kehidupan manusia (Qomario dkk, 2020). Selain hasil belajar, aktifitas juga menjadi faktor lain dalam pendidikan. Proses pembelajaran di sekolah bertujuan untuk mengembangkan potensi peserta didik dan mempersiapkan menghadapi masa depan yang lebih baik. Sehubungan dengan hal tersebut diatas, salah satu ukuran berhasil atau tidaknya proses belajar mengajar dapat dilihat dari aktivitas dan hasil belajar yang diperoleh siswa setelah mengikuti metode yang digunakan guru dalam proses pembelajaran (Juwita, 2020).

Aktifitas dalam belajar mengajar merupakan rangkayan kegiatan yang meliputi keaktifan siswa dalam mengikuti pembelajaran, bertanya hal-hal yang belum jelas, mencatat, mendengar, berpkir, membaca, dan segala kegiatan yang dilakukan yang dapat menunjang prestasi belajar (Sardiman, 1994 : 95). Belajar sambil melakukan aktifitas lebih banyak mendatangkan hasil bagi anak didik, sebab kesan yang didapatkan oleh anak didik lebih tahan lama tersimpan didalam benak anak didik (Djamarah, 2000:67).

Sadirman (1994:95) menyatakan bahwa dalam belajar sangat diperlukan adanya aktivitas belajar. Tanpa adanya aktivitas belajar itu tidak mungkin berlangsung dengan baik. Aktivitas dalam belajar mengajar merupakan rangkaian kegiatan yang meliputi keaktifan siswa dalam mengikuti pelajaran, bertanya hal-hal yang belum jelas, mencatat, mendengar, berpikir, membaca, dan segala kegiatan yang dilakukan yang dapat menunjang prestasi belajar. Usman (2000) mengatakan bahwa aktivitas belajar adalah aktivitas jasmaniah dan rohaniah, yang meliputi aktivitas sosial, aktivitas lisan, aktivitas mendengarkan, aktivitas gerak, dan aktivitas menulis.

Silberman (2009) mengemukakan bahwa paham belajar aktif memberikan gambaran tingkatan aktivitas belajar terhadap penguasaan materi yang dikuasainya, yaitu: (1) Apa yang saya dengar saya lupa, (2) Apa yang saya lihat saya ingat sedikit, (3) Apa yang saya dengar, lihat, dan tanyakan, atau diskusikan, saya mulai paham, (4) Apa yang saya dengar, lihat, diskusikan, dan lakukan, saya memperoleh pengetahuan dan keterampilan, (5) Apa yang saya ajarkan kepada orang lain, saya kuasai. Djamarah (2000:67) mengemukakan bahwa belajar sambil melakukan aktivitas lebih banyak mendatangkan hasil bagi anak didik, sebab kesan yang didapatkan anak didik lebih tahan lama tersimpan didalam benak anak didik.

Pendidikan jasmani Olahraga dan Kesehatan (Penjaskes Orkes) merupakan bagian integral dari pendidikan secara keseluruhan, bertujuan unutuk mengembangkan aspek kebugaran jasmani, keterampilan gerak, keterampilan berfikir kritis, keterampilan social,penalaran, stabilitas emosional, tindakan moral, aspek pola hidup sehat dan pengenalan lingkungan bersih melalui aktivitas jasmani olahraga dan kesehatan terpilih yang direncanakan secara sistematis dalam rangka mencapai tujuan pendidikan nasional.

Pendidikan sebagai salahsatu proses pembinaan manusia berlangsung seumur hidup, pendidikan jasmani olahraga dan kesehatan yang diajrkan di sekolah memiliki peran sangat penting, yaitu memberikan kesempatan kepada peserta didik untuk terlibat langsung dalam berbagai pengalaman belajar melalui aktivitas jasmani olahraga dan kesehatan yang terpilih yang dilakukan secara sistematis. Pembekalan pengalaman belajar itu diarahkan untuk membina pertumbuhan dan perkembangan fisik yang lebih baik, sekaligus membantuk pola hidup sehat dan bugar sepanjang hayat.

Pendidikan memiliki sasaran pedagogis, oleh karena itu pendidikan kurang lengkap tanpa adanya penjaskes orkes. Karena gerak sebagai aktivitas jasmani adalah dasr bagi manusia untuk mengenal dunia dan dirinya sendiri yang secara alami berkembang searah dengan perkembangan zaman. 
Selama ini terjadi kecenderungan dalam memberikan makna mutu pendidikan yang hanya dikaitkan dengan aspek kemampuan kognitif. Pandangan ini telah membawa akibat kebaikannya aspek moral, akhlak, budipekerti, seni, psikomotor serta life skile. Dengan diterbitkannya UU No 20 Tahun 2003 tentang Sitem Pendidikan Nasional dan Peraturan Pemerintah No 19 Tahun 2005, tentang Standar Nasional Pendidikan akan memberi peluang untuk menyempurnakan kurikulum yang kompetitif dalam rangka mencapai tujuan pendidikan nasional.

Penjas Orkes merupakan media untuk mendorong pertumbuhan fisik , perkembangan psikis, keterampilan motorik, pengetahuan penalaran, penghayatan nilainilai, sikap mental emosional, sportifitas, spiritual, social. Pembiasaan pola hidup sehat yang bermuara untuk merangsang pertumbuhan dan perkembangan kualitas fisik dan psikis yang seimbang.

Berdasarkan hasil pengamatan, wawancara dan hasil evaluasi pelaksanaan pembelajaran kebugaran Jasmani Penjas orkes di SD Negeri 4 Sawah Lama Bandar Lampung Semester genap tahun pelajaran 2018/2019 diperoleh data sebagai berikut: (1) Kegiatan pembelajaran masih banyak didominasi oleh guru, sehingga siswa kurang aktif dalam belajar, sehingga siswa kurang kreatif dalam menciptakan sebuah karya. (2) Metode yang digunakan dalam pembelajaran PKn metode ceramah, dimana informasi/konsep-konsep yang dipelajari diberitahukanatau disajikan dengan ceramah saja; (3) Dalam proses pembelajaran guru kurang memberikan penguat berupa pemberian motivasi kepada siswa.

Dari hasil evaluasi proses pembelajaran diatas, ternyata belum memberikan dampak yang baik terhadap peningkatan aktivitas dan hasil belajar siswa. Hasil ini disebabkan karena proses pembelajaran dilakukan masih menggunakan metode dan model yang membosankan dan kurang menarik perhatian siswa.

Sehubungan dengan permasalahan tersebut, maka perlu dicari solusinya, yaitu dengan melakukan perbaikan-perbaikan dalam tindakan dikelas sebagai upaya meningkatkan aktivitas belajar siswa dalam pembelajaran Penjaskes Orkes. Salah satu alternatif metode pembelajaran yang dapat digunakan untuk meningkatkan aktivitas adalah metode demonstrasi. Menurut Sanjaya (2008:152) Meode demonstrasi adalah metode penyajian pelajaran dengan memperagakan dan mempertunjukkan kepada siswa tentang suatu proses, situasi atau benda tertentu, baik sebenarnya atau hanya sekedar tiruan. Sebagai metode penyajian, demonstrasi tidak terlepas dari penjelasan secara lisan oleh guru. Walaupun dalam proses demonstrasi pesan siswa hanya sekedar memperhatikan, akan tetapi demonstrasi dapat menyajikan bahan pelajaran lebih kongkrit. Dalam strategi pembelajaran, demonstrasi dapat digunakan untuk mendukung keberhasilan strategi pembelajaran ekspositori dan inkuiri.

Dengan demonstrasi, proses penerimaan siswa dalam pelajaran akan lebih berkesan secara mendalam, sehingga membentuk pengertian dengan baik dan sempurna. Juga siswa dapat mengamati dan memperhatikan pada apa yang diperlihatkan guru dalam pembelajaran langsung.

Adapun penggunaan teknik demonsrasi mempunyai tujuan agar siswa mampu memahami tentang cara mengatur atau menyususn sesuatu misalnya penggunaan kompor untuk mendidihkan air, cara membuat sesuatu misalnya membuat kertas: dengan demonstrasi siswa dapat mengamati bagian-bagian dari sesuatu benda atau alat seperti bagian tubuh manusia, atau bagian dari mesin jahit. Juga siswa dapat menyaksikan kerjanya suatu alat atau mesin seperti penggunaan gunting dan jalannya mesin jahit. Bila siswa melakukan sendiri demonstrasi tersebut, maka ia dapat mengerti juga cara penggunaan sesuatu alat itu seperti menggunakan gunting untuk memotong kain. Dengan demikian, siswa akan mengerti cara-cara penggunaaan suatu alat atau perkakas, atau suatu mesin, sehingga mereka dapat memilih dan memperbandingkan cara yang terbaik, juga mereka 
juga akan mengetahui kebenaran dari suatu teori didalam praktek. Misalnya cara berlari yang benar.

Menurut Roestya (2008:83) tehnik lain yang hampir sejenis dengan metode demonstrasi ialah eksperimen. Tetapi siswa tidak dapat melakukan percobaan, hanya melihat saja yang di kerjakan oleh guru. Jadi, demonstrasi adalah cara mengajar dimana seorang instruktur atau tim guru menunjukkan, memperlihatkan suatu proses.

\section{Metode}

Penelitian ini dilaksanakan di SD Negeri 4 Sawah Lama Kecamatan Tanjung Karang Timur Bandar Lampung Semester Genap Tahun Pelajaran 2018/2019. Subjek dalam penelitian ini adalah siswa kleas V SD Negeri 4 Sawah Lama Kecamatan Tanjung Karang Timur Bandar Lampung Semester Genap Tahun Pelajaran 2018/2019, berjumlah 27 orang yang terdiri dari 13 siswa laki-laki dan 14 siswa perempuan. Penelitian ini dapat dikategorikan berhasil jika: $75 \%$ siswa aktif/sangat aktif mengikuti proses pembelajaran demonstrasi, dengan demikian siklus penelitian dihentikan.

\section{Hasil dan Pembahasan}

Siklus 1 dilaksanakan sebanyak 1 kali pertemuan, yaitu pada hari selasa tanggal 2 Pebruari 2019 dengan materi pembelajaran "Aktivitas untuk Kekuatan Otot". Dari hasil penelitian pada aktivitas belajar siswa pada siklus 1 terhadap 17 siswa atau 62,96\% siswa aktif mengikuti pembelajaran Penjas Orkes. Dengan demikian penelitian pada siklus 1 belum memenuhi indikator keberhasilan, sehingga penelitian ini perlu dilanjutkan pada siklus berikutnya.

Pada siklus II, dari hasil penelitian pada aktivitas belajar siswa pada siklus II terhadap 19 siswa atau 70,37\% siswa aktif mengikuti pembelajaran PKn. Dengan demikian penelitian pada siklus II belum memenuhi indicator keberhasilan, sehingga penelitian ini perlu dilanjutkan pada siklus berikutnya. Pada siklus III, dari hasil penelitian pada aktivitas belajar siswa pada siklus III terhadap 21 siswa atau 77,78\% siswa aktif mengikuti pembelajaran Penjas Orkes kebugaran jasmani. Dengan demikian penelitian pada siklus III sudah memenuhi indikator keberhasilan. Hal ini berarti tidak dilanjutkan pada siklus berikutnya.

Dari upaya perbaikan-perbaikan kinerja guru dalam penggunaan metode pembelajaran demonstrasi pada siklus III maka diperoleh eningkatan kinerja guru yaitu dari 77,08\% menjadi 87,50\% dengan kategori Sangat Baik. Hal ini berpengaruh pula terhadap peningkatan aktivitas belajar siswa dalam pembelajaran PKn yaitu dari 70,37\% menjadi 77,78\%. Dengan demikian penelitian pada siklus III sudah memenuhi indikator keberhasilan. Hal ini berarti tidak dilanjutkan pada siklus berikutnya.

Keberhasilan menggunakan metode demonstrasi tidak terlepas dari kelebihan metode demonstrasi itu sendiri. Menurut Sanjaya (2008), Kelebihan metode demonstrasi, yaitu (1) terhindar dari terjadinya verbalisme, sebab siswa disuruh langsung memperhatikan bahan pelajaran yang dijelaskan. (2) Kegiatan belajar mengajar akan lebih menarik, sebab siswa tak hanya mendengar, tetapi juga melihat peristiwa yang terjadi. Dengan cara mengamati secara langsung siswa akan memiliki kesempatan untuk membandingkan antara teori dan kenyataan.

\section{Simpulan}

Berdasarkan hasil penelitian dan pembahasan dapat disimpulkan bahwa penggunaan metode demonstrasi dapat meningkatkan aktivitas belajar kebugaran jasmani pada siswa kelas V SD Negeri 4 Sawah Lama Bandar Lampung Semester Genap Tahun Pelajaran 20010/2019. 
Jurnal Evaluasi dan Pembelajaran, 3 (1), Maret 2021 - 27

Sajidin

\section{Daftar Pustaka}

Djamarah, Syaiful Bahri. (2000). Guru dan Anak Didik dalam Interaksi Edukatif. Jakarta: Rineka Cipta.

Juwita, R. (2020). Penggunaan Model Pembelajaran Snowball Throwing Untuk Meningkatkan Aktivitas dan Hasil Belajar PKn Siswa Kelas XII IPS SMA Negeri 15 Bandar Lampung. Jurnal Evaluasi dan Pembelajaran, Vol 2(2).

Permendiknas Nomor 22. (2006). Standar Isi untuk Satuan Pndidikan Dasar dan Menengah. Jakarta: BSNP.

Qomario, Q., Tohir, A., \& Mashari, A. (2020). The effect of realistic mathematical approaches towards the students' math learning outcomes. Jurnal Prima Edukasia, 8(1), 78-85. Doi: https://doi.org/10.21831/jpe.v8i1.32577

Roestiyah N. (2008). Strategi Belajar Mengajar. PT Rhineka Cipta. Jakarta

Sardiman, AM. (1994). Interaksi dan Motivasi Belajar Mengajar. Jakarta: PT Raja Grafindo Persada.

Sanjaya, Wina. (2008). Strategi Pembelajaran. Jakarta: Kencana.

Silberman, Melvin L. (2009). Active Learning: 101 Cara Belajar Siswa Aktif. (Alih bahasa: Raisul Muttaqien). rev.ed. Bandung: Nusamedia.

Usman, Uzer. (2000). Menjadi Guru Profesional. Bandung: Remaja Rosdakarya. 